\title{
RECONSTRUCTING THE DECLARATION OF INDEPENDENCE AND THE COMMITTEE OF FIVE FOR DIGITAL NATIVES
}

\author{
Scott M. Waring \\ University of Central Florida
}

Far too often, history is taught from one, often flawed, perspective that distorts students' views of historical events. ${ }^{1}$ A good example of this is the typical student's understandings about the creation and signing of the Declaration of Independence. Too many of them think that Thomas Jefferson alone constructed the Declaration of Independence, of entirely his own thoughts, and that he completed the first, which was also the final, draft in a single day. Most believe that independence was approved unanimously on July 4, which led all of the delegates to sign the Declaration that same day. John Trumball's famous painting depicting the presentation of the Declaration of Independence provides a major impetus for the mental images constructed by our students. Finally, many think that all of the above took place in "Independence Hall," as it was known in 1776.

This is a typical version, as it is understood by many of our students, of the creation and signing of the Declaration of Independence, filled with misconceptions often learned from textbooks and websites. The essay that follows outlines an approach to teaching that attends to these misunderstandings about the Declaration of Independence and the committee of five men assigned the task of constructing that document. Since the majority of our students are "Digital Natives," "native speakers" of the digital language of computers, video games, and the Internet, ${ }^{2}$ and thrive when given an opportunity to use technology in the course of learning about history, the means utilized for this approach is the construction of an online social networking site. In addition, students need to have opportunities to go beyond their lives and develop understandings about the past that expand their thinking beyond the present. ${ }^{3}$ They need to have authentic opportunities to conduct inquiry-based explorations similar to that of historians, to develop higher-level thinking skills, and to learn that history is not

\footnotetext{
${ }^{1}$ Michael O. Tunnell and Richard Ammon, "The Story of Ourselves: Fostering Multiple Historical Perspectives," Social Education, 60, 4 (1996), 212-215; Rahima C. Wade, "Content Analysis of Social Studies Textbooks: A Review of Ten Years of Research," Theory and Research in Social Education, 21, 3 (1993), 232-256; Masato Ogawa, "Building Multiple Historical Perspectives: An Investigation of How Middle School Students Are Influenced by Different Perspectives," (2001): ERIC.
}

${ }^{2}$ Marc Prensky, "Digital Natives, Digital Immigrants," On the Horizon, 9, 5 (2001), 1-2; Marc Prensky, "Listen to the Natives," Educational Leadership. 63, 4 (December 2006), 8-13.

${ }^{3}$ Samuel S. Wineburg, Historical Thinking and Other Unnatural Acts: Charting the Future of Teaching the Past (Philadelphia: Temple University Press, 2001). 
a singular, static fact to be learned, void of investigation or interpretation. ${ }^{4}$ It is vital for students to examine primary source materials, think about contextual clues, empathize with historical agents, and interpret the past. In this way, they experience the ways in which background, bias, and values influence historical accounts. ${ }^{5}$ Various technologies, especially the Internet, have allowed educators access to a wide variety of resources outside of the classroom, so acquisition of primary sources and the development of historical thinking skills are easier today than ever. ${ }^{6}$

Ning and Spruz ${ }^{7}$ were tested and used for this activity, but other social networking sites would allow teachers to accomplish their intended goals, as well. It is important to note that the focus of this essay is on the electronic sources available, but print sources can and should be integrated when and where available and appropriate. Additionally, the focus for this project was the Declaration of Independence for utilization with middle and high school-aged students, but this approach could be used with a variety of subjects and adapted to any grade level.

\section{Historical Content to Be Acquired}

Several content-related elements are important for students to acquire during this activity. First, students need to learn that the committee chosen to write the Declaration consisted of five men: two from New England, John Adams of Massachusetts and Roger Sherman of Connecticut; two from the Middle Colonies, Benjamin Franklin of Pennsylvania and Robert R. Livingston of New York; and one Southerner, Thomas Jefferson of Virginia. Second, students should know that Jefferson constructed the first draft on his own over the span of many days, that he utilized multiple sources in its construction, and that committee members and the Continental Congress provided feedback prior to final approval. Third, students should know that Congress reconvened on July 1,1776 , and that the day after, on July 2, twelve of the thirteen states approved a resolution for independence proposed by Richard Henry Lee of

\footnotetext{
${ }^{4}$ Frederick D. Drake and Sarah Drake Brown, "A Systematic Approach to Improve Students' Historical Thinking," The History Teacher, 36, 4 (2003), 465-89; Russell Olwell, "Building Higher-Order Historical Thinking Skills in a College Survey Class," Teaching History: A Journal of Methods, 27, 1 (2002), 22-32; Cynthia Hartzler-Miller, "Making Sense of 'Best Practice' in Teaching History," Theory and Research in Social Education, 29, 4 (2001), 672-95; Linda Levstik, "Any History in Someone's History: Listening to Multiple Voices from the Past," Social Education, 61, 1 (1997), 48-51.
}

${ }^{5}$ Hartzler-Miller, "Making Sense of 'Best Practice' in Teaching History," 672-695.

${ }^{6}$ John K. Lee, "Digital History in the History/Social Studies Classroom," The History Teacher, 35, 4 (2002), 503-518.

7“"Create Your Own Social Website," http://www.ning.com and "Create and Grow Your Free Social Network," http://spruz.com. 
Virginia. The New York delegation initially abstained, but later approved the measure on July 9. Fourth, it is important to note that none of the delegates signed the Declaration on July $4 .^{8}$ It is believed that 51 of the 56 individuals affixed their signature on the engrossed copy on or around August 2, with other signers adding their names at a later date. Two members of Congress never signed, one of whom was committee member Robert R. Livingston. Thus, the famous Trumbull painting, which far too often is depicted as being a representation of the glorious moment when the signers began the procession of adding signatures, never happened as some believe and/or portray. The true intent of Trumbull is debatable, but we know that this is not a depiction of the presentation and signing of the Declaration. Last, it is obvious that not all of the events took place during one day in "Independence Hall," or the Pennsylvania State House as it was known in 1776. The teacher should point out to students that the building became known as "Independence Hall" after the Marquis de Lafayette's famous visit to Philadelphia in $1824 .^{9}$

\section{Creating a Social Network for the Committee of Five}

The first step of this class activity is to arrange the class into groups of five students, with each student assigned to take on the persona of a committee member (Adams, Franklin, Jefferson, Livingston, and Sherman). In addition to taking on the role of one committee member, each student will examine a section of the Declaration of Independence. Since the Declaration can be looked at as having five distinct parts (the introduction, the preamble, the body [broken into two sections], and a conclusion), each of the committee members, within a group of five, will focus on a different part. One also could break up the Declaration into four parts (preamble, theory, proof, and conclusion), but for pedagogical purposes, I created five parts so that there was a direct correlation with the number of committee members.

The students who are assigned the introduction should understand that this is the part in which the Congress would "declare" the "causes" for "separation" from the British Crown and Great Britain. Since this "separation" became "necessary," the preamble lays out principles, or "truths," that had become "self-evident" and the "Right of the People" to "alter or to abolish" ties with "any Form of Government" that would deprive the people of "Life, Liberty, and the pursuit of Happiness." This section closes

\footnotetext{
${ }^{8}$ It is debated whether Secretary Charles Thomson and/or John Hancock signed the Declaration on July 4 or if it was just written on a separate paper that their names would be affixed to the broadside copy being printed by John Dunlap.
}

${ }^{9}$ Before 1824 , little regard or affection was paid to the State House. During a visit from the Marquis de Lafayette in 1824, he was formally received in the "Hall of Independence" by the Mayor and other dignitaries. After this visit, greater interest in the building developed, and it later became officially known as "Independence Hall." 
by noting that the "present King of Great Britain" has a history of "repeated injuries and usurpations," all of which were done for the sole purpose of establishing "an absolute Tyranny over these States." The students assigned to the first section of the body should understand that this portion gives examples of the "repeated injuries and usurpations" perpetrated against the American colonists by King George III. It is valuable for students to investigate critically the long list of charges against George III and how exaggerated some, if not many, of them were and just why Thomas Jefferson took this approach. Students should know that the second section of the body points out the colonists' appeals to their "British brethren" and their "native justice and magnanimity" that were left unheard. Finally, in the conclusion, it should be made clear that the Congress, as representatives of the United States of America, decided to "solemnly publish and declare, That these United Colonies are, and of Right ought to be Free and Independent States; that they are Absolved from all Allegiance to the British Crown, and that all political connection between them and the State of Great Britain, is and ought to be totally dissolved."

Once each student is fully aware of his or her role and the section of the Declaration on which to focus, a good introductory reading, depending upon the age of the students, might be Russell Freedman's Give Me Liberty! The Story of the Declaration of Independence, "The Declaration of Independence: A History," found on the National Archives and Records Administration's website, or Pauline Maier's American Scripture: Making the Declaration of Independence. ${ }^{10}$ Additional suggestions can be found in the Appendix.

Next, the instructor should present students with the guidelines for the structure and expectations for the Ning site. An example can be found at http://independence. ning.com. Within the structure of the Ning site, or similar social networking sites, students have an opportunity to construct a page about themselves, or in this case about their assigned committee members. The webpage can include images and a personal narrative, as well as many other selected elements. A "Committee Members" page with biographical information and images can be posted about each of the committee members. There also can be a page constructed for the Declaration of Independence where each of the five parts can be discussed by the committee member assigned to that part. In addition to the elements discussed here, students can add videos, chat boxes, text boxes, web links, and many other elements to customize the site. Another important element to include is a timeline of events leading up to, during, and after the July meeting of the Congress. If time permits during construction of the Ning sites, it would be helpful to allow all of the students assigned a particular individual to have an

\footnotetext{
${ }^{10}$ Russell Freedman, Give Me Liberty! The Story of the Declaration of Independence (New York: Holiday House, 2000); National Archives and Records Administration, "The Declaration of Independence: A History," http://www.archives.gov/exhibits/charters/declaration_history.html; Pauline Maier, American Scripture: Making the Declaration of Independence (New York: Knopf, 1997).
} 
opportunity to meet and discuss what they found; this helps build and fill in gaps of content-related understandings. This will help them to be fact checkers for one another for the information found and presented about his or her assigned committee member and for the section of the Declaration for which they have been assigned.

For construction of the narratives, students should be instructed to use multiple sources of information and cite them properly. For the four committee members who were also signers (Adams, Franklin, Jefferson, and Sherman), the following websites would be helpful in the construction of the narratives. (For other sites, articles, and books, see the Appendix.)

"Signers of the Declaration: Biographical Sketches,"http://www.nps.gov/history/ history/online books/declaration/bioa.htm

"Index of Signers by State," http://www.ushistory.org/declaration/signers/index. htm

"Colonial Hall: The Biographies of the Founding Fathers," http://colonialhall. com/biodoi.php

For Robert Livingston, the only committee member who did not sign the Declaration, the following websites should be useful:

"Robert Livingston," http://www.ushistory.org/declaration/related/livingston_r. htm

"Robert Livingston," http://www.aoc.gov/cc/art/nsh/livingston.cfm

Answers.com, a metasite that lists results from numerous websites, can be useful for students and can be a perfect platform for a discussion on the existence of multiple presentations and representations of history and the lives of historical agents:

"John Adams: Biography," http://www.answers.com/topic/john-adams

"Benjamin Franklin: Biography," http://www.answers.com/topic/benjaminfranklin

"Thomas Jefferson: Biography," http://www.answers.com/topic/thomas-jefferson

"Roger Sherman: Biography," http://www.answers.com/topic/roger-sherman

"Robert Livingston: Biography,"http://www.answers.com/topic/robert-livingston

Additionally, this would be a perfect time to include a discussion of Wikipedia, describing how entries are constructed, discussing the validity of Wikipedia as a source, and so forth, as the majority of our students use it with or without our consent. Thus, it is in our best interest to instruct them about the good, bad, and ugly of Wikipedia.

The process of constructing the narrative allows students an opportunity to utilize a variety of sources, including primary sources. The goal is to increase historical understandings and empathy within our students. For example, the student assigned to 
Thomas Jefferson might believe that he was the primary designer and author of the Declaration, using as part of this assertion a letter from Jefferson to James Madison on August 30,1823 , in which he noted that the committee of five:

... unanimously pressed on myself alone to undertake the draught. I consented; I drew it; but before I reported it to the committee, I communicated it separately to Dr. Franklin and Mr. Adams requesting their corrections; because they were the two members of whose judgments and amendments I wished most to have the benefit before presenting it to the Committee; and you have seen the original paper now in my hands, with the corrections of Doctor Franklin and Mr. Adams interlined in their own hand writings. Their alterations were two or three only, and merely verbal. I then wrote a fair copy, reported it to the Committee, and from them, unaltered to Congress. ${ }^{11}$

Additional sources could include a mixture of letters, like the above, documents, such as Jefferson's "original Rough draught" that includes alterations made by Adams, Franklin, and other members of the committee and Congress, ${ }^{12}$ paintings and engravings, including a copy of the engraving entitled "Congress Voting the Declaration of Independence," a contemporaneous print representing the committee of five delegates submitting their draft to the Continental Congress on June $28,1776,{ }^{13}$ as well as a plethora of other available electronic sources. Students should have an opportunity to utilize a variety of sources to sift through the documentary record to construct plausible narratives for each of the committee members and rationale and basis for the construction of the Declaration of Independence and each of its parts.

\section{Additional Resources}

There are numerous websites that will help capture interest and provide additional documents for the students and their research. One such location is the National Archives and Records Administration's website where students are given an

\footnotetext{
${ }^{11}$ Thomas Jefferson to James Madison, August 30, 1823, http://rotunda.upress.virginia.edu/founders/ defalut.xqy?keys=FOEA-print-02-02-02-0027.

${ }^{12}$ Thomas Jefferson's "original Rough draught," June 1776, http://www.loc.gov/exhibits/treasures/ trt001.html.

${ }^{13}$ Edward Savage's Engraving (unfinished), "Congress Voting the Declaration of Independence" (c. 1776), LC-USZ62-6078-A, http://www.loc.gov/exhibits/declara/images/voting.jpg.
} 
opportunity to sign the Declaration of Independence. ${ }^{14}$ Also on this website, visitors have an opportunity to download high resolution copies of the Declaration of Independence and other original documents. ${ }^{15}$ The Library of Congress' website provides a page with over eighty documents, images that can be used to bolster the teaching of the American mindset at this time and the creation of the Declaration of Independence, with a section detailing its legacy. ${ }^{16}$ If one is going to discuss the John Trumbull painting, the "Interactive John Trumball's Declaration of Independence" website allows users to scroll over any of the men represented and find out his identity. ${ }^{17}$

\section{Conclusion}

Giving students an opportunity to take on the role of one of the committee members should correct their main misunderstandings about the construction and signing of the Declaration of Independence. They now should understand that Thomas Jefferson did not construct the Declaration alone in a single day relying entirely on his own thoughts. They will have a different mental image of the John Trumball painting, knowing that it is not an accurate depiction of the approval and signature by each member of Congress on July 4 in Independence Hall. Most importantly, students will begin to understand that the Revolutionary era was filled with real people making colossal decisions and that not all won unanimous and harmonious agreement. The approach described here will help students to gain a better understanding of the Declaration of Independence and the committee assigned to its creation, utilizing a pedagogical approach that is infused with learning methods of interest and familiarity to the Digital Native population in our schools today.

\section{Selected Bibliography}

Armitage, David. The Declaration of Independence: A Global History (Cambridge: Harvard University Press, 2007).

\footnotetext{
${ }^{14}$ National Archives and Records Administration, "Join the signers of the Declaration of Independence," http://www.archives.gov/exhibits/charters/declaration_join_the_signers.html.

${ }^{15}$ National Archives and Records Administration, "Charters of Freedom," http://www.archives,gov/ exhibits/charters/declaration.html.

${ }^{16}$ Library of Congress. Creating the United States, http://myloc.gov/Exhibitions/creatingtheus.

${ }^{17}$ Quiz Tree, "Interactive John Trumbull's Declaration of Independence," http://www.quiz-tree.com/ Declaration-of-Independence-Trumbull.html.
} 
Becker, Carl Lotus. The Declaration of Independence: A Study on the History of Political Ideas (New York: Harcourt, Brace and Co., 1922).

Boyd, Julian P. The Declaration of Independence: The Evolution of the Text (Charlottesville: International Center for Jefferson Studies at Monticello, 1999).

Dupont, Christian Y., and Peter S. Onuf, eds. Declaring Independence: The Origin and Influence of America's Founding Document (Charlottesville: University of Virginia Library, 2008).

Gerber, Scott Douglas, ed. The Declaration of Independence: Origins and Impact (Washington, DC: CQ Press, 2002).

Maier, Pauline. American Scripture: Making the Declaration of Independence (New York: Knopf, 1997).

\section{For Younger Readers}

Burgan, Michael. The Declaration of Independence (Minneapolis: Compass Point Books, 2001).

Fink, Sam. The Declaration of Independence: The Words That Made America (Scholastic, 2002).

Fradin, Dennis B. The Signers: The Fifty-Six Stories Behind the Declaration of Independence (New York: Walker, 2002).

Freedman, Russell. Give Me Liberty! The Story of the Declaration of Independence (New York: Holiday House, 2000).

Gragg, Rod. The Declaration of Independence: The Story Behind America's Founding Document and the Men Who Created It (Nashville: Rutledge Hill Press, 2005).

Graves, Kerry A. The Declaration of Independence: The Story Behind America's Founding Document (Philadelphia: Chelsea Clubhouse, 2004).

Nardo, Don. The Declaration of Independence (San Diego: Kidhaven Press, 2003).

St. George, Judith. The Journey of the One and Only Declaration of Independence (New York: Philomel Books, 2005).

Yero, Judith Lloyd. The Declaration of Independence: American Documents (Washington, DC: National Geographic Society, 2006). 